ロシンポジウム $\mathbb{N}:$ エビデンスのある認知症のリハビリテーション

\title{
コミュニケーション支援におけるエビデンスの可能性 一言語聴覚士の立場から自験例を通して一
}

\author{
飯 干 紀代子*
}

\begin{abstract}
要旨：Alzheimer 病（以下, $\mathrm{AD})$ のコミュニケーション障害の類型化と, それに基づくタイプ別の コミュニケーション支援の自験例を提示し, 日常臨床とエビデンスとの関係，今後の可能性につい て論じた。第 1 に, Ward 法を用いたクラスター分析の結果, $\mathrm{AD}$ のコミュニケーション障害は, 全 体高型, 聴覚障害型, 認知障害型, 構音障害型, 全体低型の 5 つに分類された。第 2 に, 認知障害 型に実施した集団での包括的認知訓練では, $\mathrm{AD}$ 群にドネペジル治験と同等あるいは一部上回る MMSE 総得点の変化を認めた。第 3 に, 聴覚障害型に実施した口形提示が単語の聴こえに及ほす効 果の検証では, 中〜重度の聴覚障害を伴う $\mathrm{AD}$ に著明な効果を認めた。認知症のコミュニケーショ ン支援では, 高いエビデンスレベルの trial を試みる一方で, 原因疾患や重症度別の詳細な分析や薬 効との比較といった仮説検証型の日常臨床の重積が，EBM 実践における自己評価として特に重要な 意味を持つと考えられた。

(高次脳機能研究 32 (3) ：468～476，2012）
\end{abstract}

Key Words : 認知症, コミュニケーション障害, 類型化, 非薬物療法, 聴覚障害

dementia, communication disorder, cluster analysis, nonpharmacological therapy, hearing difficulty

\section{はじめに}

コミュニケーションとは，2 者間で何らかの概 念や情報を交換する行為であり，人の生活手段と して欠くことができないばかりでなく，人として の存在の根幹をなす活動のひとつでもある。認知 症者においては, 原因疾患や脳の損傷 - 変性部位 により症状に違いはあるものの, その多くが失語 症や構音障害を呈する。そこに加齢による聴覚や 視覚といった感覚レベルの障害も加わり, 認知症 者の $70 \%$ 以が何らかのコミュニケーション障害 を持つと報告されている（黒田ら 1995, 植田ら 1999, 飯干ら 2001)。これらのコミュニケーショ ン障害は, 医療, 介護といった認知症者を取り巻 く生活に広く影響を及ぼす。介護困難や介護負担 感の大きな要因（Potpkins ら 2003, 小川ら 2006) であることに加え, 認知症者本人の認知機能低下 を加速 (Uhlmann ら 1986, Peters 1988, Lin ら 2011）させることも指摘されている。
さて，コミュニケーションは，病前の教育・職 業・性格, 現在の身体状況・意欲といった様々な 個人因子の影響を受ける。加えて, コミュニケー ション相手の属性も関与するため, 評価や介入の 条件や方法を厳密に統制しがたい側面がある。ま た，本邦においては，コミュニケーション障害に 対する支援を主として担う言語聴覚士（以下，ST) の臨床現場が，認知症多数例に少人数で対応せざ るを得ない状況（綿森 2002，中村ら 2005）であ ることも, 介入効果に関するエビデンスの検証を 一層困難にしている。

本報告では，STの立場から，エビデンスのある リハビリテーションの出発点のひとつと考えられ るコミュニケーション障害の類型化の試みと, そ れに基づくタイプ別の支援について Alzheimer 病 （以下，AD）を主とした自験例を提示する。そし て, 日常臨床におけるコミュニケーション支援を エビデンスという観点から分析し，その可能性に ついて考察する。 
なお，本報告におけるすべての研究は，九州保 健福祉大学倫理審査委員会の承認を受け, 対象お よび家族に個別に承諾を得た上で実施された。

\section{I. study1.}

\section{コミュニケーション障害の類型化}

\section{1. 目的}

コミュニケーションの基本的構成要素である, 聴覚, 認知, 言語, 構音機能の評価結果を基に $\mathrm{AD}$ のコミュニケーション障害を類型化し，支援 方法の基礎資料を得る。

\section{2. 対象}

対象は, National Institute of Neurological and Communicative Disorders and Stroke-Alzheimer's Disease and Related Disorders Association（以下, NINCDS-ADRDA）により probable $\mathrm{AD}$ と診断さ れた 3 つの介護保険関連施設入所中の連続 78 例 （男性 21 例，女性 57 例）であり，平均年齢は $80.4 \pm 8.0$ 歳, Mini Mental State Examination（以 下, MMSE) 平均は $16.8 \pm 5.4$ 点であった。

\section{3. 検査手続き}

聴覚：オージオメータ (MADSEN MIDIMATE 602）を用い，気導純音聴力検査を実施した。欠損 デー夕低減と所要時間短縮のため, 測定周波数を $0.5,1 ， 2 ， 4 \mathrm{KHz}$ の 4 周波数に限定した。一方で, 通常の応答ボタン押しに加え挙手や領きなどの聴 性行動反応を闇值判定基準として追加した。4 分 法による良聴耳の平均聴力レベルを分析対象とし た。

認知：杉下ら（2010）の施行手続きにより, MMSE を実施した。前述の平均聴力レベルとミネ ソ夕式臨界読書文字検査日本版（小田 2000）の結 果を参考に，対象が十分に聞こえる大きさの声と， 識別可能なフォントサイズの文字で MMSE を施行 した。以下，言語および構音検査も同様の教示・ 提示条件に倣った。

言語：言語機能検查（飯干ら 2007）を実施した。 聴覚的理解, 視覚的理解, 発話, 書字の言語の 4 モダリティについて単語と短文レベルの処理機能 を評価するものであり, 最大得点は 22 点である。

構音：構音機能検査（飯干ら 2007）を実施した。 発話の明瞭度を, 1 (発話内容が十分わかる) から
5 (話題を知っていても発話内容がまったく分から ない）の， 0.5 ステップ 9 段階で評定した。

\section{4. 類型化手続き}

各検査のデータ值を標準得点に変換した。クラ スター分析にはW Ward 法を用い，デンドログラム を作成した。得られたクラスター数を基に $2-$ step クラスター分析を行った。分類に用いた変数を従 属変数に, クラスターを独立変数にした分散分析 を実施し，その後の多重比較にBonferroni を用い た。統計ソフトは, study2, 3 の分析を含め, SPSS for Windows 16.0 を用いた。

\section{5. 結果と小括}

5 つのクラスターが抽出され, 多重比較検定の 結果, 各クラスターは以下の特徵を示した（図1）。 タイプ 1 は構音に障害を示す「構音障害型」で, 発話内容はほぼ適切だが明瞭度が低下しており， 重度 $\mathrm{AD}$ でなければ義歯欠損・不適合や声量不足 による見かけ上の構音障害である可能性が高かっ た。タイプ 2 は中等度以上の聴覚障害のある「聴 覚障害型」で, 左右差のある例は少なく, 聴覚障 害のため音声言語は不良だが文字言語は保存され ていた。タイプ 3 は認知機能, 中でも記憶と見当 識が低下している「認知障害型」で, 表面的なや りとりは成立するが内容が不適切であった。夕イ プ 4 は全体的に高得点な「全体高型」で, コミュ ニケーション機能が全般的に良好であり, 概ね意 思疎通可能であった。タイプ 5 は全体的に低得点 な「全体低型」で, 単語の理解や意志表示も困難 であった。

\section{II. study2. 認知障害型に対する包括的認知訓練}

\section{1. 目的}

複数の原因疾患・異なる重症度の認知症者を対 象に実施した集団での認知訓練について, MMSE 下位項目得点の変化, 服薬効果との対比を指標と して, 認知障害型 $\mathrm{AD}$ に対する介入効果を検証す る。なお，包括的とは，対象がセレクトされてい ない, 訓練内容が領域特異的でないという意味で 用いる。

\section{2. 対象}

対象は画像診断, 認知機能検査, 心理 - 行動症 


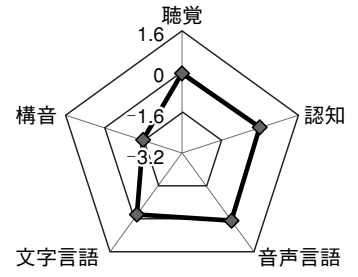

構音障害型

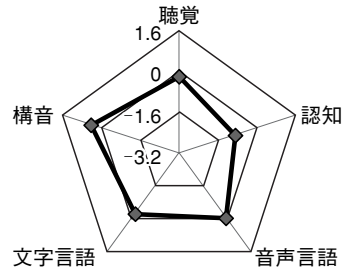

認知障害型

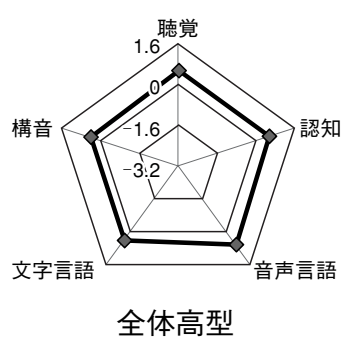

全体高型

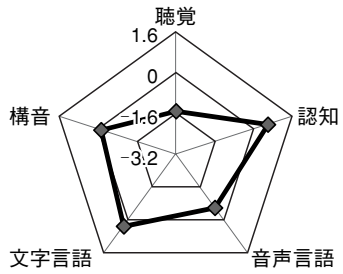

聴覚障害型

図1 類型化による5つのタイプ

候評価をもとに医師が認知症と診断した療養型病 床入院中の連続 63 例（男性 22 例, 女性 41 例）で, 平均年齢は $75.8 \pm 7.1$ 歳, MMSE 平均 $22.7 / 30 \pm$ 4.0 点であった。原因疾患別では, $\mathrm{AD} 15$ 例, 脳血 管障害型 26 例, Lewy 小体型 10 例, その他 12 例 であり，そのうち $\mathrm{AD}$ については全例 NINCDSADRDA による probable $\mathrm{AD}$ の条件を満たした。認 知症の重症度（森ら 1985, Kurlowicz ら 1999）は, 軽微（MMSE 24 30 点) 26 例, 軽度 (同 21 23 点), 中等度（同 $10 \sim 20$ 点）であった。 $\mathrm{AD}$ は 全例塩酸ドネペジルを服薬しており, 訓練期間中 の投薬量変更はなかった。

\section{3. 訓練方法}

週 1 回 60 分のセッションを 16 回実施した。 1 セ ッションの構成は, 訓練目的説明, 見当識確認, 認知訓練, 再度の見当識確認であった。そのうち 認知訓練については, 言語, 空間・構成, 計算, 注意・記憶, 遂行の 5 領域に分けて作成したプロ グラム, 例えば, 語想起, 寸劇, 生け花, 水彩画, 買物計画と釣銭計算などから 1 つ選んで実施した。 対象者の生活歴の尊重, errorless-effortless な手続 き, 残存能力を発見し賞賛する態度を共通の遵守 事項とした。訓練は, 毎回, 同じ時間帯に同じ場 所で行った。

\section{4. 結果および小括}

MMSE 得点変化を 2 元配置分散分析で分析する のが妥当であるが，該当例がゼロとなるセルが生 じたため対応のある $\mathrm{t}$ 検定を実施した。訓練前後 の MMSE 平均得点の比較では, 原因疾患別で $\mathrm{AD}$ が 1.4 点 $(\mathrm{t}=2.6, \mathrm{df}=14, \mathrm{p}=0.05), \mathrm{DLB}$ が 1.4 点 $(\mathrm{t}=2.7, \mathrm{df}=10, \mathrm{p}=0.05)$, 重症度別で軽度 群が 1.6 点（ $\mathrm{t}=2.7, \mathrm{df}=15, \mathrm{p}=0.05 ）$ の有意な 上昇を認めた（図 2)。 $\mathrm{AD}$ に対するドネペジルの 治験のうち MMSE が本研究と同程度で，かつ本訓 練実施期間 16 週に近い報告では，服薬による MMSE 得点上昇は 0.4 から 1.3 点である（Seltzer ら 2004, Winblad 2006, 井上ら 2007, Tanaka ら 2008)。本研究では 1.4 点の上昇を認め, 服薬 単独での効果とほぼ同等, あるいは一部上回る結 果が得られた。

MMSE 下位項目得点の分析では, 対象全体 $(\mathrm{t}=2.6, \mathrm{df}=62, \mathrm{p}=0.05), \mathrm{AD}(\mathrm{t}=2.8, \mathrm{df}=$ $14, \mathrm{p}=0.05), \operatorname{DLB}(\mathrm{t}=2.7, \mathrm{df}=10, \mathrm{p}=0.05)$ が見当識項目, 軽度群において見当識 $(\mathrm{t}=3.2$, $\mathrm{df}=15, \mathrm{p}=0.05)$ と言語 $(\mathrm{t}=2.6, \mathrm{df}=15$, $\mathrm{p}=0.05 ）$ 項目が有意に上昇した。

体調不良以外の久席はなく, 出席率は $93.7 \%$ と 非常に高かった。行動観察所見では, 訓練への出 


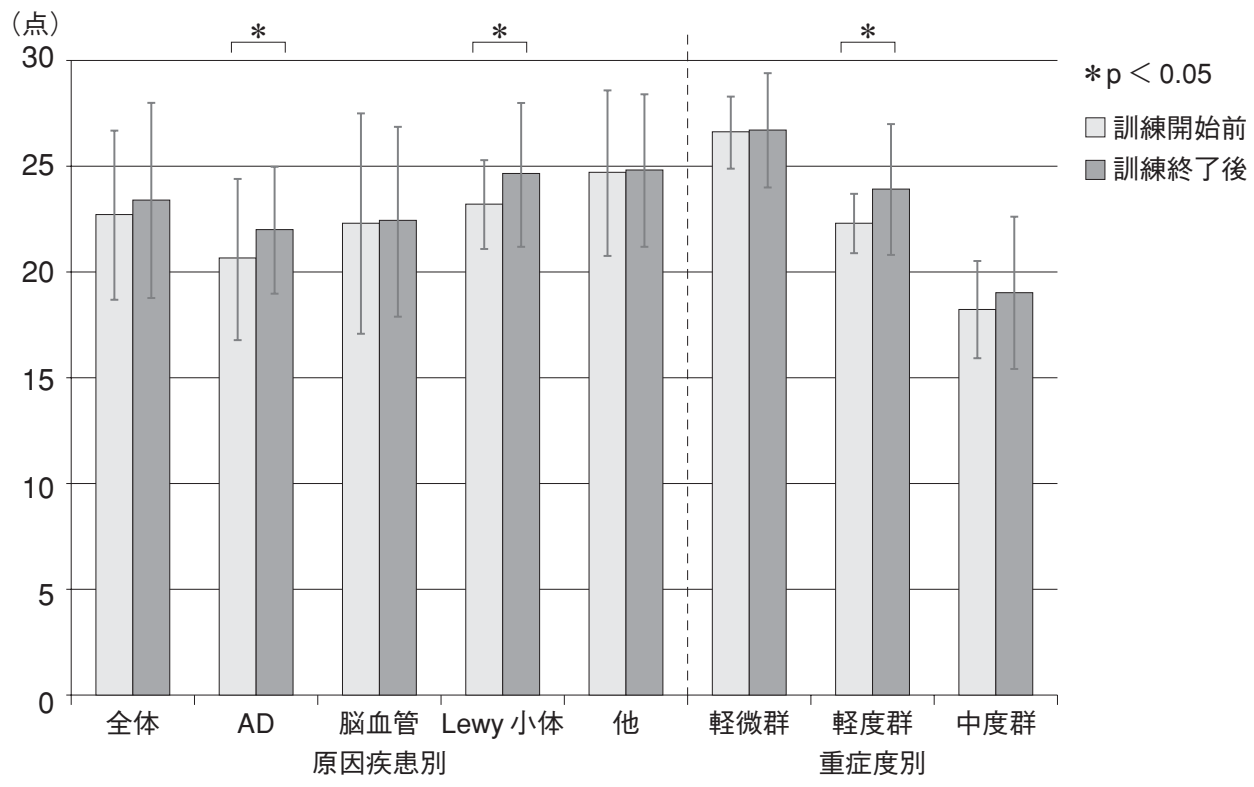

図 2 MMSE の得点変化

迎えを準備して待つ, 日常生活でカレンダーや時 計への関心が増えたことなどが特筆され，本訓練 が生活リズム形成や見当識獲得のきっかけになっ ていることが伺えた。

\section{III. study3. \\ 聴覚障害型に対する \\ コミュニケーション支援方法}

\section{1. 目的}

聴覚障害型 $\mathrm{AD}$ に対するコミュニケーション支 援方法として，発話者が口形を提示することによ る単語の聴こえの促進効果を検証する。

\section{2. 対象}

対象は，3つの介護保険関連施設に入所中で, NINCDS-ADRDAにより probable AD と診断され た連続 80 例（男性 23 例，女性 57 例）で，平均年 齢は $81.7 \pm 9.5$ 歳, MMSE 平均点は $16.8 \pm 6.0$ 点, 教育歴は $9.0 \pm 2.0$ 年であった。

\section{3. 実施手続き}

聴覚: 気導純音検査を study1 前述の通りに行っ た。WHO 基準（Mathersら 2000）により，平均 聴力レベル $25 \mathrm{dBHL}$ 以下を normal, $26 〜 40 \mathrm{dBHL}$ を slight, $41 \sim 60 \mathrm{dBHL}$ を moderate, $61 \sim 80$
dBHL を severe，81 dBHL 以上を profound に分類 した。

単語の聴こえ： 67 語表の了解度検査用 20 単語 （日本聴覚医学会 2003）を用いた。STが対象の正 面約 $1 \mathrm{~m}$ より, 普通の大きさの声（サウンドレベ ルメータ RION NL 22 にて 50〜 60 dBSPL) で単語 を聞かせ，復唱させた。1対象に，口形提示あり， 口形提示なしの 2 条件を実施した。口形提示あり 条件では，対象にSTの口もとを注視させた後， 復唱するよう求めた。口形提示なし条件では, ST の口を白紙で覆い，口形を見せないようにした状 態で, 復唱するよう求めた。両条件をランダムに 施行して順序効果を相殺した。STの声の音圧は両 条件で差異はなかった。正しく復唱できた単語数 を正答数とした。

MMSE：実施，重症度分類ともに study1の通り であった。

\section{4. 結果と小括}

聴覚障害重症度別の正答数は, normal が $20.0 \pm$ 0.0 (100\%), slightが $18.8 \pm 2.8$ (94\%), moderate が $16.9 \pm 3.0(84 \%)$ ， severeが $11.6 \pm 6.0$ (58\%) であった。聴覚障害の重症度に応じて正 答数は低下し，平均聴力レベルが $61 \mathrm{dBHL}$ 以上に 
なると単語の 3 分の 1 程度しか聴き取れていない ことが示された。

口形提示の有無を被験者内要因, 聴覚障害を被 験者間要因とする 2 要因分散分析の結果, 口形提 示の主効果 $(\mathrm{F}(1,76)=34.57, \mathrm{p}<0.01)$ と交互 作用 $(\mathrm{F}(3,76)=9.78, \mathrm{p}<0.01)$ が有意であっ た。単純主効果の検定では, 聴覚障害中等度（F $(3,76)=30.28, \mathrm{p}<0.01)$, 重度 $(\mathrm{F}(3,76)=$ 49.26, $\mathrm{p}<0.01 ）$ において口形提示の効果が有意 であった（図 3)。同様に，MMSE を被験者間要 因とした結果, 口形提示の主効果は認めたが（F $(1,76)=36.48, \mathrm{p}<0.01)$, 交互作用は認めなか った $(\mathrm{F}(3,76)=0.64, \mathrm{NS})$ 。

以上より，中〜重度の聴覚障害のある $\mathrm{AD}$ に対 する口形提示の有効性が示された。口形提示は, $\mathrm{AD}$ の残存能力の一つである音韻系機能（Bayles 1992, Vigliocco 2000, Giaud ら 2001, Nota ら 2004）を賦活し，単語の聴こえを促進したと考え られた。

\section{IV. 総合考察}

1. エビデンスのあるコミュニケーション支援 の出発点としての類型化

3つの自験例を通して, 認知症者に対するコミ ユニケーション支援におけるエビデンスについて 整理する。study1では, $\mathrm{AD}$ のコミュニケーショ

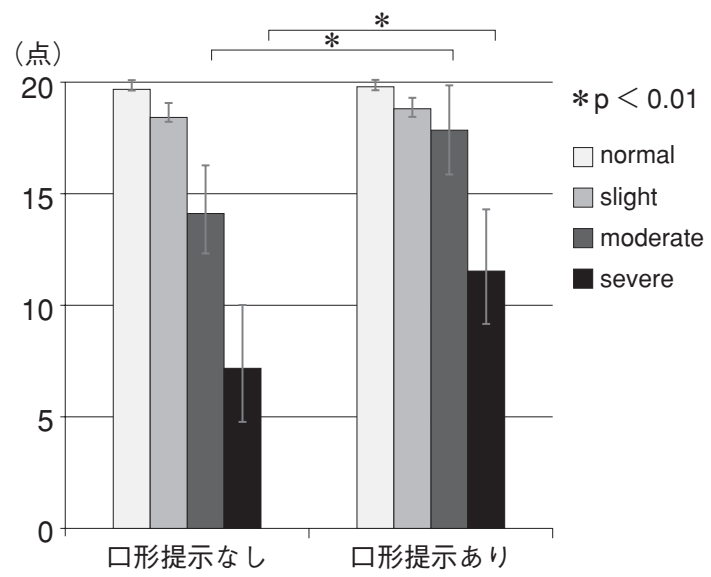

図 3 聴覚障害の重症度別にみた口形提示効果
ン障害について類型化を試み, 聴覚障害型, 認知 障害型，構音障害型，全体高型，全体低型の 5 つ のタイプを抽出した。Stopfordら（2007）は AD

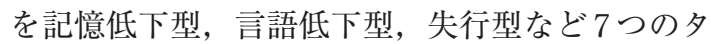
イプに分類しているが，タイプごとの症状分析の 記述にとどまり支援方略には言及していない。本 研究は, 聴覚と視覚といった感覚入力系を含むコ ミュニケーションの基本的構成要素に着目した点, 分類結果が支援方略に直結する点で, $\mathrm{AD}$ に対す るエビデンスのあるコミュニケーション支援の出 発点としての基礎資料を提供しえたと考える。

\section{2. 進行中の支援をエビデンスレベル分析する}

\section{意義}

類型化したタイプのうち，認知障害型を聴覚障 害型を対象とした study2 と 3 は, エビデンスレベ ル判定ではIV : 分析疫学的研究, gradeでは $\mathrm{c}$ : 行 うよう勧めるだけの根拠がない，という位置づけ である。しかし，両 study ともエビデンス判定基 準のうち, 認知症の原因疾患 - 重症度 - 症状別, 除外基準の設置，群間比較は満たしており，今後， random control trial (以下, RCT) の条件，すなわ ち, コントロール群設定, 無作為割り付け, 盲検 化を図ることでレベル II へと移行可能である。

$\mathrm{AD}$ に対するSTの支援について American Speech and Hearing Association が行った 1975 年か ら 2002 年のメタアナリシス（Eatherら 2006, Mahendraら 2006 a,b) では, エビデンスレベル II （1つ以上の RCT） と判定された trial は 13 件で あった。その後, 1999 年から 2008 年の分析結果 （Olazaran ら 2010）では, 134 件と約 10 倍に増加 している。両者のキーワードに若干違いがあるた め厳密に比較できないものの, エビデンスレベル の向上には RCTに至らない多くの trial を重ねる時 期が必要であることが推察される。本邦の ST の 臨床現場はサンプル収集や無作為化に向けた環境 整備が脆弱であるが，進行中の支援をエビデンス 判定基準の達成と未達成という観点で正確に分析 し，不足を補う試みを臨床の中で着実に蓄積して いくことは，エビデンスのあるコミュニケーショ ン支援を実現する準備段階であると考える。 


\section{3. 日常臨床が evidence based medicine の step5に果たす役割}

エビデンスに基づく医療 (evidence based medicine, 以下, EBM) は, 通常, 以下 4 つのステッ プを経て実践される（福井 1999）。すなわち，臨 床上の問題の導出 (step1), 最適なエビデンスデ ータの検索 (step2)，レベルと推奨度の高い方法 を選択（step3），患者への実践（step4）である。 しかし, 現実には, 合併症や身体状態増悪のため リハ施行条件を変える, $\mathrm{AD}$ に有効性の高いとさ れるリハを複数の原因疾患や重症度から構成され る認知症者集団に施行するなど，選択した方法を 目の前の患者にそのまま適用できない状態が多発 する。むしろ, 集団訓練の場合, 脳血管性認知症 者の寡黙を $\mathrm{AD}$ の多弁が補う, 軽度認知症者が重 度者をサポートするなど，変法することにより臨 床的意義が高まる場合もある。

したがって，認知症に対する EBMでは， step5 と言われる実践の自己評価，つまり，選択した方 法の適切性や効果を判定し, 必要に応じて修正す る過程が, 特に必須と言える。具体的には, study2 で示した定期評価による認知機能変動の確 実な把握や服薬効果との対比, 原因疾患・重症度 別の分析，あるいは study3 で示した臨床症状と病 巣の照合といった日常臨床の重積であり, これら は認知症者に対する $\mathrm{EBM}$ 継続のための地道だが 欠くことのできない基礎研究であると考える。

\section{4. エビデンスのあるコミュニケーション支援}

\section{の other side}

冒頭で述べたように，コミュニケーションは人 としての存在の根幹という側面を持つことから， 認知症者に対するコミュニケーション支援は，生 理学的・神経心理学的な機能維持や生活活動促進 に加え, 人間哲学的あるいは人生の質への洞察が 求められる。ICF 分類における活動参加, 個人 · 環境因子の重視とも換言できるが，これらの客観 的評価は難しく, 現時点ではエビデンスレベルを 判定し難い領域である。

中等度難聴を伴う $\mathrm{AD}$ 例（80 歳代男性・介護保 険関連施設入所）を通して，コミュニケーション 支援の other side に触れる。症例は MMSE 11 点で, 難聴のためテレビやレクリェーションにも無関心
で，他者交流もなく傾眠がちの日常であった。 我々がコミュニケーション支援の一環として行っ ている, 生い立ちから現在にいたる生活史を聴取 し, 写真やイラストとともにアルバムにまとめる メモリーブック（Bourgeois 1990，1993）を用い たプログラムを実施したところ, 水道配管工をし ていた 30 歳代の頃について, 配管の種類や值段, 接続の仕方など多彩な用語を使って滔々と語り, 最後に,「仕事は段取りが大切です。人生も同じで す」と締めくくった。

このエピソードは, 一瞬の出来事であり, 偶然 による不確実性や主観性が高く, エビデンスレベ ルはVI（デー夕に基づかない意見）である。しか し, STが難聴の重症度に適した音圧で, 口形を見 せて, 理解力に合わせた文節数で問いかけ, 記憶 の時間的勾配を考慮した本人に価值のある時代に 絞って質問を掘り下げる, といったコミュニケー ション機能の詳細な分析に基づく働きかけの結果, 生まれたエピソードであるとも言える。このよう な人生の知恵とも言える言葉を引出し, それを共 有する瞬間を持つことは, 認知症のコミュニケー ション支援を考える際, 本質的に大切なことの一 つと思われる。効果の客観的判定は容易ではない が, 今後, テキスト分析などにより検証性を高め る必要のある領域と考える。

謝辞 : ご助言・ご助力いただいた行橋記念病院の 本村暁先生, パールランド病院の猪鹿倉忠彦先生, Ohio State University の Bourgeois MS 先生, 国際医 療福祉大学の深浦順一先生, 九州保健福祉大学の山 田弘幸先生，大森史隆先生に深謝いたします。

本研究は科学研究費補助金（基盤研究 C 22500494, 研究代表者：飯干紀代子）「認知症のコミ ユニケーション障害に対する包括的アプローチ方法 の開発」の助成を受けて行われた。

\section{文献}

1) Bayles, K. A. : Relation of linguistic communication abilities of Alzheimer patients to stage of disease. Brain Lang., 42 : 454-472, 1992. 
2 ) Bourgeois, M. S. : Enhancing conversation skills in patients with Alzheimer's disease using a prosthetic memory aid. Journal of Applied Behavior Analysis, 23 : 29-42, 1990.

3 ) Bourgeois, M.S. : Effects of memory aids on the dyadic of individuals with the dementia. Journal of Applied Behavior Analysis, 26 : 77-87, 1993.

4 ) Eather, S., Kim, M. S., Sturt, J., et al. : EvidenceBased Practical recommendations for Working with Individuals with Dementia : Group Reminiscence Therapy. Journal of Medical SpeechLanguage Pathology, 14 : 23-34, 2006.

5 ) 福井次矢: EBM 実践ガイド。医学書院, 東京, 1999, pp. 48-72.

6 ) Giaud, A. L. \& Price, C. J. : The constraints functional neuroimaging places on classical models of auditory word processing. J. Cogn. Neurosci., $13: 754-765,2001$.

7 ) 飯干紀代子, 倉内紀子, 田上美年子, ほか：延 岡市の福祉施設における言語聴覚障害児・者の 実態について。九州保健福祉大学紀要, 2：211216, 2001.

8 ) 飯干紀代子, 倉内紀子：介護老人保健施設にお ける言語および構音スクリーニング検査に関す る検討。音声言語医学，48：201-209, 2007.

9 ) 井上 淳, 星野良一, 野島秀哲, ほか：塩酸ド ネペジル（donepezil hydro-chloride）の認知機 能に及ぼす効果の臨床的検討。老年精神医学, 18 : 993-1002, 2007.

10) Kurlowicz, L. \& Wallance, M. : The Mini Mental State Examination (MMSE). Journal of Geriatric Nursing, $25:$ 8-9, 1999.

11）黒田喜寿, 黒田理子, 高橋 克：施設居住高齢 者のコミュニケーション障害に関する予備的調 査. 総合リハビリテーション，23：1071-1074, 1995.

12) Lin, F. R., Metter, E. J., O’Brien, R. J., et al. : Hearing loss and incident dementia. Arch. Neurol., $68: 214-220,2011$.
13) Mahendra, N., Hopper, T., Bayles, K. A., et al. : Evidence-Based Practical recommendations for Working with Individuals with Dementia : Montessori-Based Interventions. Journal of Medical Speech-Language Pathology, 14 : 1525, 2006a.

14) Mahendra, N., Bayles, K. A., Bayles, K. A., et al. : Evidence-Based Practical recommendations for Working with Individuals with Dementia : Computer-Assisted Cognitive Interventions. Journal of Medical Speech-Language Pathology, $14: 35-44,2006 \mathrm{~b}$.

15) Mathers, C., Smith, A. \& Conch, M. : Global burden of hearing loss in year 2000. Global Burden Disease, 2000 : 1-30, 2000.

16）森 悦朗, 三谷祥子, 山鳥 重: 神経疾患患者 に打ける日本語版 Mini-Mental State テストの有 用性。神経心理学, 1：82-90, 1985.

17）中村やす, 高橋育子, 山本弘子, ほか：介護保 険施設に打ける言語聴覚療法の現状と課題。言 語聴覚研究, $2 ： 41-47,2005$.

18) 日本聴覚医学会: 語音聴覚検査法. Audiology Japan, 46 ： 622-637, 2003.

19) Nota, Y. \& Honda, K. : Brain regions involved on motor control of speech. Acoustical Science and Technology, $25 ：$ 286-289, 2004.

20）小田浩一：ミネソタ読書チャート MNREAD-J. 眼科診療プラクティス, $57: 79,2000$.

21）小川郁男, 山崎 博：高齢者聴覚検診体制の確 立一難聴は寝たきりや認知症のリスク要因。埼 玉県医学会雑誌，41：269-278, 2006.

22) Olazaran, J., Reisberg, B., Clare, L., et al. : Nonpharmacological therapies in Alzheimer's Disease : A systematic Review of Efficacy. Dementia Geriatric Cognitive Disorder, 30 : 161178, 2010.

23) Peters, C. A., Potter, J. F., Scholer, S. G. , et al. : Hearing Impairment as a Predictor of Cognitive Decline in Dementia. Journal of American Geri- 
2012 年 9 月 30 日

atrics Society, 36 : 981-986, 1988.

24) Potpkins, D., Myint, P., Bannister, C., et al. : Language impairment in dementia : impact on symptoms and care needs in residential homes. International Journal Geriatric Psychiatry, 18 : 1002-1006, 2003.

25) Seltzer, B., Zolnouni, P., Nunez, M., et al. : Efficicacy of Donepezil in Eraly-Stage Alzheimer Disease. Neurol., 61 : 1852-1856, 2004.

26) Stopford, C. L., Snowden, J. S., Thompson, J. C., et al. : Variability in cognitive presentation of Alzheimer's disease. Cortex, 44 : 185-95, 2007.

27）杉下守弘, 逸見 功, JADNI 研究：MMSE-J （精神状態短時間検査一日本語版）の妥当性と信 頼性について一A preliminary report. 認知神経科 学, $12: 186-190,2010$.

28) Tanaka, T., Kazui, H., Morohara, T., et al. : Postmarking survey of donepezil hydrochloride in Japanese patients with Alzheimer's disea-se with behavioral and psychological symptoms of
(475) 123

dementia (BPSD). Psychogeriatrics, $8: 114-123$, 2008 .

29）植田 恵, 笹沼澄子, 杉原素子, ほか：老人保 健施設入所痴呆高齢者の高次脳機能と ADLの特 徴に関する調査研究。国際医療福祉大学紀要, $4: 79-105,1999$.

30) Uhlmann, R. F., Larson, E. B. \& Koepsell, T. D. : Hearing impairment and cognitive decline in senile dementia of the Alzheimer's type. J. Am. Geriatr. Soc., 34 : 207-210, 1986.

31) Vigliocco, G. : Language processing : the anatomy of meaning and syntax. Current. Biol., $10: 78-80,2000$.

32) 綿森淑子：高齢者施設における言語聴覚士の役 割とは. 聴能言語学研究, 9：29-34, 2002.

33) Winblad, B., Wimo, A., Engsdal, K., et al. : 3-Year Study of Donepezil in Alzheimer's Disease ; Effects of Early and Continuous Therapy. Dementia and Geriatr. Cog. Disord., 21 : 353363, 2006. 
Abstract

\title{
Possibility of obtaining evidence regarding communication support for dementia - Trials of speech language and hearing therapist -
}

\begin{abstract}
Kiyoko Iiboshi*
Classification of individuals with Alzheimer's disease $(\mathrm{AD})$ based on their communication deficits was performed and communication support for each type of deficit was investigated. The relationship between the daily clinical activities of speech and hearing therapists and the provision of evidence based medicine (EBM) for individuals with $\mathrm{AD}$ is discussed. When cluster analysis of the communication deficits of individuals with probable $\mathrm{AD}$ was done by Ward's method, five types were identified ; 1) general high, 2) hearing difficulty, 3) cognitive difficulty, 4) speech difficulty, and 5) general low. After comprehensive cognitive group therapy was provided for the cognitive difficulty type, the Mini Mental State Examination score of individuals with probable $\mathrm{AD}$ exceeded the scores obtained in several previous clinical trials assessing the efficacy of donepezil hydrochloride. When displaying mouth movements during listening to words was investigated for the hearing difficulty type, probable $\mathrm{AD}$ patients with moderate or severe hearing loss showed significant improvement of aural comprehension compared to their comprehension without showing mouth movements. We should try to obtain high-level evidence for communication therapy such as by performing a randomized controlled trial. In addition, it is particularly important for the selfevaluation of EBM for individuals with dementia to develop investigations during daily clinical activities, such as analysis of the effect on each type of dementia or grade of severity and comparison with the effects of medication, in order to generate and verify hypotheses.
\end{abstract}

*Shigakukan University Department of Clinical Psychology. 1-59-1, Murasakibaru, Kagoshima city, Kagoshima 890-8504, Japan 